the first six or seven days it preferred to stand on its heels, and usually rose to its toes, that is, the normal position of the adult, only when walking.

The bird often ate indigestible things, little stones, \&c., not, as it appeared to me, altogether accidentally, but chiefly and purposely, after it had made a good meal off some living food-Tenebrio larvæ, Limnæus, or the like. Smaller edible things like ants' chrysalids it picked off the ground itself very early, but larger morsels, bits of fish, mice, \&c., it only takes when held in the hand and presented to it even now, when it is eight weeks old. The stones, \&c., it occasionally eats, and the hair and larger bones it has swallowed it brings up and vomits in a mass. It lost the thorn of the beak on the fourth day and began to fly a little after four weeks ; when seven weeks old it began to make longer excursions, and flewwithout precept or example-very well. It has, however, not yet attained to anything like the elegant flight of full-grown gulls, and occasionally makes an involuntary somersault in the air when trying to soar or rest on the wind without flapping its wings.

Prague.

R. v, LENDENFELD.

\section{The Effect of Light on Cyanin.}

WHILE working on the reflective power of cyanin mirrors I have noticed some very interesting effects of light on that substance. Freshly fused cyanin is of a deep metallic bronze colour, but exposure to light turns it plum colour and finally a steely blue-black. In the moderate light of a cloudy day the change is perceptible in half an hour, in direct sunlight in less than a minute. The complete change to blue-black requires an exposure of about twenty hours to diffuse daylight or half an hour to direct sunlight. It has long been known that cyanin is un. suitable for use as a cloth dye on account of its rapid fading in sunlight, but recent investigators of the optical properties of this substance appear to have overlooked this light effect. That the effect is purely photographic and not due to any rise in temperature is shown by the fact that long-continued heating in the dark produces no trace of discoloration. On the contrary, the effect of heating is to reverse the effect produced by the light, for a thin coating of cyanin, exposed until blue-black throughout, returns nearly to its original bronze colour on fusion or longcontinued heating in the dark. By an exposure of thirty hours I have obtained on cyanin easily recognisable photographs of small, well-illuminated objects. A cyanin mirror, or better yet a piece of ground glass washed over with fused cyanin, exposed for ten hours to the spectrum of a Nernst lamp shows the effect to be very strong in the yellow, just perceptible in the adjacent red and green, and imperceptible in the blue and ultra-violet. It appears to correspond with the absorptive index as determined by Pfiiger in various parts of the spectrum. At the same time, the exposure to light greatly decreases the absorbing power where it was originally large, as may be easily seen on looking at a sodium flame or a spectrum through an exposed coating of cyanin. It is as though the absorption were due to molecular resonance and the light produced a fatigue or destruction of this resonating power.

A most noteworthy change in the refractive index accompanies this change in the absorptive index, and is shown by the alteration in the reflecting power. The reflecting power of fresh cyanin is roughly 20 per cent. in the yellow, 2 per cent. in the blue-green and 6.5 per cent, in the ultra-violet. After exposure to light the reflecting power is nearly constant, 6.5 per cent., from the red out to $250 \mu \mu$ in the ultra-violet. Now in the blue-green the absorptive index is so small as not to affect the reflecting power sensibly, so that the refractive index varies from about $I$ 'I to $I \cdot 6$. Evidently work on the optical constants of cyanin is of little value unless carried on without exposure of the cyanin to daylight. A decrease in the absorptive index from 0.75 to nearly zero is indicated by the decrease in the reflecting power in the middle of the yellow, where exposure to light does not. greatly affect the refractive index. The general effect of exposure to light is, then, to remove the absorption band and to destroy the characteristic anomalous dispersion.

The cyanin used was furnished by Kahlbaum, in Berlin, and is the ordinary diamyl iodide, $\mathrm{C}_{29} \mathrm{H}_{33} \mathrm{~N}_{2} \mathrm{I}$, easily soluble in alcohol and ether, but only very slightly soluble in water.

Göttingen, August. P. G. NutTing.

\section{Fog Bow at Oxford.}

A somewhat curious phenomenon, presumably an effect caused by the searchlights at Spithead, was visible here in Oxford on the night of Saturday last.

About II.15 p.m., the night being fine and warm and the sky somewhat overcast, my attention was arrested by the appearance of an arc of whitish light, about $15^{\circ}$ above the south horizon, within which the sky appeared of an intense black. The arc rapidly increased in elevation until, in six or seven minutes' time, it had reached the zenith, forming an arch extending, apparently, to the horizon on the east and west; it then declined northwards, and in another four or five minutes had vanished.

In appearance it suggested a brilliant lunar fog bow, but the light was of a more bluish tint, the interior circumference being far brighter than the outer; the brilliancy did not diminish to any great extent until the bow attained its highest altitude, after which it rapidly become fainter. The distance from Spithead is rather more than seventy miles.

Rawlinson Road, Oxford, August 20.

J. Rose.

\section{Simple Means of Producing Diffraction Effects.}

IN the interesting article on "Photography of Diffraction and Polarisation" published in the issue of NATURE for August 7 , the writer describes various means of producing diffraction effects. It may possibly interest some readers of NATURE to know that beautiful fringes may be seen with even simpler ap. paratus than that described in the article referred to. All that is required is an ordinary folding foot-rule, preferably of ivory. To see diffraction bands by its means, it is only necessary to close the two halves of the rule until they are almost in contact and then to fold them over. On looking at the sun or other bright source of light through both slits, a series of brilliant diffraction bands will be seen.

Tynemouth, August 20.'

\section{Time-Signals by Wireless Telegraphy.}

MAY I suggest that the wireless telegraph offers a means of enabling Greenwich or other astronomical time being sent to ships at sea for the correction of their chronometers and the finding of their longitude? Distinct signals have already been transmitted from England to America, and these are all that is necessary for communicating time. At certain hours of the day or night, for example I p.m., a series of wireless signals, perhaps ten or twenty, at intervals of one second, might be sent from Greenwich far and wide as an extension of the time-ball signal which now serves for ships in the Thames and the Downs. By international regulation these time-signals could be protected from other wireless signals. I need scarcely add that such timesignals would also be useful inland.

JOHN MUNRO.

Croydon, August 25.

\section{THE BELFAST MEETING OF THE BRITISH} ASSOCIATION.

SINCE the publication of our last article on the approaching meeting, the following additional arrangements have been made :-

The local executive committee (chairman, Sir Otto Jaffe) invites members, associates and holders of ladies' tickets to a garden party in Botanic Gardens Park, near Queen's College, on September 15, at 3 to 5.30 p.m.

In connection with this reception, the new fernery recently arranged by Mr. Charles McKim, curator of the Botanic Gardens, will be opened for the first time, and will be found well worth seeing by those interested in ferns and tropical plants.

On September 16, Lord O'Neill gives a garden party at Shane's Castle, picturesquely situated on the shore of Lough Neagh.

The Belfast Harbour Commissioners invite members, associates and holders of ladies' tickets to a reception in the Harbour Office on September I6, at 8 p.m. 